Dr. Ir. Dahri Tanjung, M.Si, Safira Fathun, SE., M.Sc.

\title{
Program Pemulihan Bisnis UMK Terdampak Covid-19 di Wilayah Bogor
}

\author{
Dr. Ir. Dahri Tanjung, MSi \\ Sekolah Vokasi IPB University, Bogor \\ Safira Fathin SE., M. Sc. \\ Universitas Borobudur, Jakarta \\ Email: dahritanjung@careipb.or.id
}

\begin{abstract}
Abstrak
Bencana Covid-19 telah memberi berdampak buruk terutama terhadap kesehatan dan ekonomi. Usaha mikro dan kecil (UMK) merupakan sektor ekonomi yang sangat terdampak. Sementara posisi UMK demikian besarnya dalam ekonomi daerah, sehingga begitu pentingnya membantu UMK untuk segera bangkit dari terpaan Covid-19 tersebut.Tujuan penelitian terapan ini adalah menganalisis dampak Covid-19 dan menyusun program pemulihan bisnis UMK menghadapi kondisi normal. Metode Analisis yang digunakan dalam penelitian ini adalah analisis deskriptif tabulasi dan grafis, dan analisis pemasaran. Hasil analisis menunjukkan sebagian besar $(75 \%)$ merupakan wanita yang berumur 30-50 tahun. Dari responden penelitian ini, sebanyak 40\% bergerak dibidang usaha makanan ringan dan minuman. Hasil uji paired samples terhadap asset, biaya dan keuntungan menunjukkan bahwa sebelum pandemi jauh berbeda dibandingkan dengan setelah pandemi. Untuk itu program pemulihan UMK yang perlu dilakukan yaitu penyiapan izin usaha, perbaikan kualitas produk, dan pengembangan digital marketing.
\end{abstract}

Kata Kunci: dampak Covid-19, program pemulihan, UMK

\section{Pendahuluan}

Wabah Corona Virus Disesase (Covid-19) telah ditetapkan sebagai bencana nasional di Indonesia berdasarkan Keputusan Presiden No 12 Tahun 2020 tentang Penerapan Bencana Non Alam Penyebaran Corona Virus Disease. Bencana Covid-19 ini telah berdampak pada berbagai sektor terutama kesehatan dan ekonomi. Dampak pandemi Covid-19 ini terhadap usaha kecil dan menengah (UKM) telah disebutkan oleh Pakpahan (2020), dimana ada sekitar 37.000 UKM yang memberikan laporan bahwa mereka terdampak sangat serius. Ada kurang lebih $56 \%$ melaporkan terjadi penurunan penjualan, 22\% melaporkan permasalahan pada aspek pembiayaan, 15\% melaporkan pada masalah distribusi barang, dan 4\% melaporkan kesulitan mendapatkan bahan baku mentah. Menurut data Badan Pusat Statistik (BPS), kontribusi UKM terhadap Produk Domestik Bruto (PDB) Indonesia mencapai 61,41\% pada tahun 2018. Tentu kontribusi ini menunjukkan peran UKM sebagai tulang punggung ekonomi nasional Indonesia.

Dalam menghadapi tantangan wabah Covid-19, sebenarnya sektor UMK merupakan sektor yang mampu menangkap peluang dari kondisi saat ini, terutama untuk UMK yang sudah terhubung dengan digitalisasi. UMK berbasis online memiliki ketahanan yang lebih baik dibandingkan dengan offline. Proses digitalisasi UMK dapat menurunkan biaya operasional sehingga mendorong penggunaan waktu dan sumber daya lebih efisien melalui dukungan teknologi untuk pemasaran produk maupun proses transaksi melalui platform online.

Namun demikian berbagai kendala masih menghambat UMK dalam mengakses teknologi tersebut. UMK yang terutama di perdesaan tidak mudah melakukan hal tersebut 
Dr. Ir. Dahri Tanjung, M.Si, Safira Fathun, SE., M.Sc.

mengingat kondisi perdesaan tidak sememadai seperti di perkotaan. Terbatasnya akses ke infrastruktur dasar serta kapasitas sumber daya manusia (SDM) yang belum memadai menyebabkan perdesaan identik dengan kondisi ketertinggalan. Selain itu, pola pikir yang belum mampu beradaptasi dengan perubahan teknologi yang semakin maju juga turut menghambat proses transformasi digitalisasi. Berdasarkan Kementerian Koperasi dan UKM, saat ini pelaku UMKM di Indonesia hanya $5 \%$ yang sudah menggunakan teknologi sedangkan sisanya masih konvensional.

Untuk mendukung proses digitalisasi UMKM di perdesaan, perlu adanya dukungan berupa pengembangan kapasitas SDM yang memadai yang dicapai melalui beberapa langkah strategis berupa peningkatan kompetensi SDM melalui pendidikan formal dan non formal serta penguatan modal sosial. Peningkatan kapasitas SDM melalui pendidikan non formal dapat dicapai melalui sosialisasi dan pelatihan penggunaan teknologi informasi serta pendampingan. Mengingat demikian besarnya dampak wabah Covid-19 ini serta begitu pentingnya membantu UMK untuk segera bangkit dari terpaan Covid-19 tersebut, maka kegiatan penelitian ini perlu untuk dilakukan.

\section{Metode Penelitian}

\section{Waktu, Lokasi dan Responden}

Kegiatan ini dilaksanakan dari Agustus-Desember 2020. Adapun lokasinya di beberapa desa/kelurahan di Kabupaten dan Kota Bogor yang merupakan sentra UMK yang paling terdampak Covid-19. Penelitian ini dilakukan dengan metode survey dan data utama yang dikumpulkan adalah data primer dari responden ditambah data sekunder. Sebanyak 71 responden adalah yang memiliki usaha yang tergolong mikro dan kecil. Sampel dipilih secara proporsional berdasarkan jenis usaha yaitu produsen/pengolahan.

\section{Metode Analisis}

Kondisi sosial ekonomi rumah tangga masyarakat umum, pengusaha UMK digambarkan secara deskriptif naratif. Mengalisis kondisi bisnis UMK digunakan analisis Before and After yang bertujuan untuk membandingkan saat sebelum pandemi Covid dan setelah terjadi pandemi. Salah satu faktor yang mempengaruhi bisnis UMK adalah konsumen pembeli. Menurunnya secara drastis jumlah pembeli karena kebijakan PSBB, seperti social distancing, belajar atau bekerja dari rumah merupakan masalah besar dalam kondisi pandemi ini.

Pada sample UMK, maka beberapa variabel yang diukur adalah yang terkait dengan aspek usaha seperti omzet, biaya dan keuntungan. Variabel-variabel ini diolah menggunakan program SPSS 16.0 dan diuji secara statistik. Analisis data menggunakan uji Paired Samples T-test yang bertujuan untuk menguji hipotesis penelitian ini, yaitu mengetahui perbedaan kondisi bisnis UMK sebelum dan sesudah terjadinya pandemi Covid-19. Rumus T-test untuk dua sampel berpasangan (Paired Samples T-test) secara lengkap seperti di bawah ini:

$$
\mathrm{t}=\frac{\bar{X}_{1}-\bar{X}_{2}}{\sqrt{\frac{s_{1}^{2}}{n_{1}}+\frac{s_{2}^{2}}{n_{2}}-2 r\left(\frac{s_{1}}{n_{1}}\right)\left(\frac{s_{2}}{n_{2}}\right)}}
$$

Keterangan:

$\mathrm{t}=$ nilai $\mathrm{t}$ yang dihitung

$\mathrm{s}^{1}=$ simpangan baku UKM sebelum Covid

$\mathrm{s}^{2}=$ simpangan baku UKM setelah Covid

$\mathrm{n}_{1}=$ jumlah anggota UKM sebelum Covid

$\mathrm{r}=$ koefisien korelasi $\mathrm{n}_{2}=$ jumlah anggota UKM setelah Covid

$\mathrm{x}_{1}=$ nilai rata-rata $\mathrm{UKM}$ sebelum Covid

$\mathrm{x}_{2}=$ nilai rata-rata UKM setelah Covid 
Dr. Ir. Dahri Tanjung, M.Si, Safira Fathun, SE., M.Sc.

Hipotesis dalam penelitian ini adalah:

$H 0$ : Tidak terdapat perbedaan yang signifikan antara kinerja keuangan sebelum dan setelah Krisis.

$H 1$ : Terdapat perbedaan yang signifikan antar kinerja keuangan sebelum dan setelah Krisis Pandemi.

Dari hasil pengujian yang dilakukan, maka tolak $H 0$ apabila (1) $p$-value $<\alpha$ dan (2) t hitung $>$ $\mathrm{t}$ tabel atau $-\mathrm{t}$ hitung $<-\mathrm{t}$ tabel.

\section{Analisis Pemasaran}

Pemasaran adalah sistem keseluruhan dari kegiatan usaha yang ditujukan untuk merencanakan, menentukan harga, mempromosikan dan mendistribusikan barang dan jasa yang dapat memuaskan kebutuhan pembeli maupun pembeli potensial (W. Stanton 2012). Perkembangan teknologi digital dan internet sangat berpengaruh pada pemasaran dunia. Teknologi dan pemasaran dapat dikaitkan sebagai pola yang saling memberi keuntungan satu sama lain. Jika tidak ada teknologi maka pemasaran akan menjadi terbelakang dan tidak akan maju untuk memenuhi tuntutan zaman. Maka perlu adanya pengetahuan peran dan dampak teknologi di bidang pemasaran. Hal ini akan merubah tren pemasaran di dunia beralih dari yang semula konvensional (offline) menjadi digital (online).

Saat ini semuanya menjadi elektronik marketer menggunakan teknologi untuk melakukan kegiatan usaha. E-marketing menciptakan, berkomunikasi, dan memberikan proses nilai kepada pelanggan yang menggunanakan sistem teknologi informasi, untuk mengelola dan memelihara hubungan dengan pelanggan untuk mendapatkan manfaat bagi organisasi atau perusahaan dengan para stakeholder (J.a.F.R. Strauss 2009). E-marketing menggunakan metode teknologi informasi ke dalam prinsip-prinsip pemasaran. Dengan demikian aspek yang akan dianalisis dalam pemasaran ini antara lain, aspek pasar, metode pemasaran yang digunakan apakah tatap muka (offline) atau sudah menggunakan digital marketing (online), serta aspek konsumen.

\section{Pembahasan}

\section{Keragaan Responden}

Responden yang dipilih untuk penelitian ini menunjukkan bahwa $75 \%$ berjenis kelamin perempuan, dan secara umum sebanyak 52,5\% responden berusia 30-50 tahun. Dengan melihat data tersebut, dapat disimpulkan bahwa responden pelaku UMK penelitian ini didominasi oleh pelaku ibu rumah tangga yang mencoba membuat produk-poduk UMK untuk dipasarkan. Untuk informasi sosial berkaitan dengan umur responden, sebanyak 52,5\% responden yang berumur 30-50 tahun, sebayak 35\% adalah pelaku UMK dengan umur 20-30 tahun yang merupakan kaum milenial yang mencoba terjun membuka usaha UMK.

Informasi sosial lainnya adalah tingkat pendidikan responden, dimana $70 \%$ responden memiliki tingkat pendidikan dengan lulusan SMA/SMK, 15\% lulusan SMP, 10\% lulusan SD dan 5\% lulusan D3. Dari informasi tersebut didapat bahwa lebih dari setengahnya/mayoritas responden berpendidikan SMA/SMK yang dengan lulusan SMA/SMK tersebut akan lebih mudah memanajemen suatu bisnis karena sudah mengerti dan belajar dari bangku sekolah terlebih untuk lulusan SMK. Dengan begitu, pelaku UMK diharapkan bisa menerima informasi dan dapat mengoperasikan digital marketing dengan baik.

\section{Informasi terkait Usaha Responden}

Informasi terkait usaha responden dengan memberikan beberapa pertanyaan tentang usaha yang dijalankan masing-masing responden. Informasi ini digunakan sebagai langkah 
Dr. Ir. Dahri Tanjung, M.Si, Safira Fathun, SE., M.Sc.

awal untuk mendeskripsikan dan menilai usaha yang dijalankan. Adapun pertanyaanpertanyaan terkait informasi usaha tersebut antara lain:

a) Bidang usaha

Dari responden penelitian ini, sebanyak $40 \%$ bergerak dibidang usaha makanan ringan dan minuman, $15 \%$ dibidang dagang, 7,5\% dibidang kerajinan, 30\% dibidang industri makanan, 2,5\% dibidang industri minuman, 2,5\% dibidang kesehatan dan kecantikan, lalu 2,5\% dibidang kuliner. Menurut responden, usaha makanan-minuman memiliki peluang yang besar untuk masuk ke pasar yang lebih luas, karena tren saat ini sudah banyak makananminuman kekinian dan makanan-minuman inovatif yang bermunculan sehingga dengan beragamnya jenis makanan-minuman, semakin besar pula peluang bisnis tersebut.

b) Spesifikasi Usaha

Sebanyak 22,5\% responden memiliki usaha dengan spesifikasi usaha makanan kering, dan yang lainnya adalah makanan basah $(7,5 \%)$, serta roti dan mie (5\%). Menurut responden, makanan kering merupakan salah satu usaha makanan yang memiliki resiko produk yang minim, hal ini karena makanan kering dapat diproduksi dan dijual dalam jangka panjang (tidak cepat basi) sehingga jika produk tidak habis terjual dalam satu hari, maka dapat disimpan untuk dipasarkan dihari berikutnya. Dengan begitu, pelaku UMK dapat menghemat cost yang dikeluarkan untuk setiap produksi.

c) Izin legalitas yang dimiliki

Sebanyak 40,5\% mayoritas pelaku UMK yang memiliki legalitas NIB (Nomor Induk Berusaha) dan 24,4\% sudah memiliki izin P-IRT. Izin legalitas yang dimiliki pelaku UMK sangat bervariasi mulai dari P-IRT $(24,4 \%)$, IUMK $(21,6 \%)$, HO (0\%), Halal $(5,4 \%)$, dan yang lainnya. Menurut info yang didapat dari hasil wawancara secara langsung kepada pelaku UMK, mereka masih kesulitan dalam mengurus izin legalitas usaha karena prosedur yang rumit, biaya yang mahal, serta masih kurangnya informasi dalam mengurus izin tersebut. Sehingga masih banyak pelaku UMK yang belum bisa memenuhi perizinan usaha yang ditetapkan oleh pemerintah.

d) Rata-rata jumlah produksi (unit) per minggu

Sebanyak $40 \%$ responden pelaku UMK memiliki tingkat produksi yang sangat sedikit yaitu sekitar 5-50 unit per minggu. Kondisi tersebut dikarenakan masih terkendalanya modal yang dimiliki dan waktu produksi mereka yang tidak berlanjutan, sehingga mayoritas pelaku UMK akan memproduksi bila ada pesanan. Namun jika tidak ada pesanan sangat jarang sekali mereka melakukan proses produksi.

e) Jumlah tenaga kerja

Sebanyak $70 \%$ pelaku UMK tidak merekrut pekerja dari luar, melainkan mereka mengandalkan tenaga kerja dari dalam (keluarga) untuk membantu proses produksi produk yang dijual. Hal ini menurut mereka dapat menekan biaya produksi untuk bayar tenaga kerja luar yang lumayan mahal, sehingga mereka memanfaatkan tenaga kerja dalam keluarga, dan mengalokasikan dana upah tenaga kerja luar untuk keperluan yang lain seperti pembelian bahan baku dan yang lainnya. Jumlah tenaga kerja responden dapat dilihat pada Gambar 1.

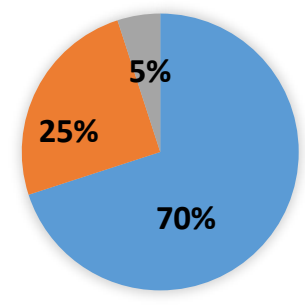

Keterangan:

Gambar 1. Jumlah tenaga kerja

Tidak ada (hanya TK dalam keluarga

1-2 orang

2-3 orang 
Dr. Ir. Dahri Tanjung, M.Si, Safira Fathun, SE., M.Sc.

f) Cara mengolah produk

Sebanyak 35\% pelaku UMK mengolah produknya dengan cara digoreng dengan minyak, pertanyaan ini masih berkaitan dengan pertanyaan sebelumnya terkait spesifikasi usaha yang mayoritas memiliki usaha makanan kering, seperti kita ketahui bahwa mayoritas makanan kering diolah dengan cara digoreng dengan minyak. Cara mengolah produk pelaku UMK lainnya dengan cara direbus sebesar $22,5 \%$, dikeringkan dengan oven $27,5 \%$, dipresto $2,5 \%$, dan ditiriskan dengan spinner sebesar $5 \%$.

g) Kemasan yang dipakai

Sebanyak $71,8 \%$ pelaku UMK menggunakan plastik sebagai kemasan produk yang dihasilkan, hal ini karena masyarakat Indonesia yang sudah terbiasa menggunakan kemasan plastik sebagai kemasan makanan terutama makanan kering, selain itu juga harga dari kemasan plastik yang ekonomis. Beberapa kemasan yang dipakai oleh pelaku UMK antara lain botol $(5,1 \%)$, karton $(5,1 \%)$, daun $(2,6 \%)$, gelas plastik $(5 \%)$, pot $2,6 \%$, standing pouch $5,2 \%$, dan kardus $2,6 \%$.

h) Cara pemasaran

Sebanyak 53,3\% pelaku UMK menggunakan cara pemasaran dengan menggunakan jual sendiri di rumah, hal ini karena para pelaku UMK lebih mudah dengan menjual produk sendiri dirumah karena dengan menjual sendiri dirumah para pelaku UMK lebih mudah dalam mejualnya selain dalam menjualnya dirumah yaitu dengan tidak adanya perizinan seperti mengurus surat sewa ruko, membayar sewat tempat, pajak uang keamanan dan lainlainnya serta di rasa para pelaku UMK lebih efektif dan efesien. Hasil cara pemasaran yang dilakukan para pelaku UMK yang menjual produknya di luar rumah sebesar 35\%, selebihnya di jual di warung atau toko (12\%).

i) Sistem pembayaran dengan konsumen

Sebanyak 70\% pelaku UMK menggunakan sistem jual putus (kontan) dikarenakan dalam pengembalian modal dan keuntungan dirasa mudah didapat apabila dengan cara sistem pembayaran jual putus karena menurut para pelaku UMK dengan pembayaran jual putus akan lebih pasti dan arus kas akan lancar, oleh sebab itu para pelaku UMK lebih menyukai pembayaran dengan jual putus (kontan) tetapi tidak memungkinkan bahwasannya para pelaku UMK menerima dengan sistem pembayaran konsiyiasi dan cash. Pelaku UMK juga melakukan sistem pembayaran dengan konsinyasi (25\%) dan tunai $(5 \%)$.

j) Sumber pembiayaan

Sebanyak $82,5 \%$ pelaku UMK menggunakan sumber pembiyaan dengan menggunakan sumber dana pribadi, tetapi tidak memungkinkan pelaku usaha menggunakan sumber pinjaman dari pihak luar seperti pinjaman bank, koperasi dan lain-lainnya. Sumber dana pribadi akan lebih efektif dan aman karena terhindar dari bunga baik dari bank dan pihak-pihak lainnya, sehingga para pelaku usaha tidak terbebani oleh bunga dan mereka bisa lebih fokus untuk mengembangkan usahanya. Sumber pembiayaan lainnya juga diperoleh dari pinjaman (15\%) dan pribadi pinjaman $(2,5 \%)$.

\section{Informasi terkait dampak pandemi Covid-19 terhadap usaha}

Terkait dampak pandemi Covid-19 terhadap keberlangsungan usaha, yang merupakan salah satu analisis output yang dihasilkan dari penelitian ini, dengan mengajukan beberapa pertanyaan sehingga hasil akhirnya mendapatkan kesimpulan yang diinginkan. Adapun hasil responden terkait dampak pandemi Covid-19 terhadap usahanya antara lain:

a) Sebanyak 40,78\% pelaku UMK mengalami masalah pemasaran produk saat pandemi seperti ini, dimana masih banyak produk-produk mereka yang tidak terserap oleh pasar, karena menurunnya daya beli masyarakat dengan adanya WFH dan pembatasan untuk melakukan 
Dr. Ir. Dahri Tanjung, M.Si, Safira Fathun, SE., M.Sc.

kegiatan diluar rumah sehingga produk-produk yang pelaku UMK pasarkan sulit terjual dan berakibat pada menurunnya omzet usaha. Permasalahan lainnya yang dihadapi oleh UMK akibat adanya pandemi Covid-19 yaitu masalah perizinan $(23,68 \%)$, masalah peralatan $(19,73 \%)$, dan masalah permodalan $(15,81 \%)$.

b) Dengan adanya pandemi Covid-19 ini, sebesar 65\% pelaku UMK yang dirugikan dengan adanya pembatalan transaksi jual beli. Pembatalan transaksi tersebut bisa dibedakan pembatalan transaksi jual beli langsung dan pembatalan transaksi jual beli produk secara online. Informasi pembatalan transaksi dapat dilihat pada Gambar 2.
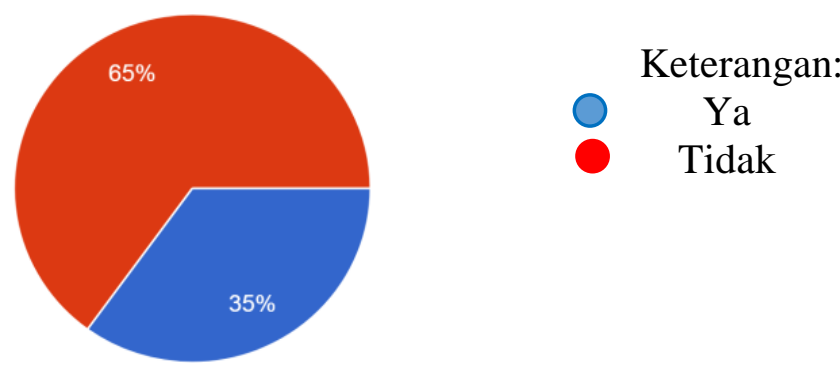

Gambar 2. Pembatalan transaksi pada saat pandemic

c) Dengan adanya pandemi Covid-19 ini, pelaku UMK dituntut untuk memasarkan produknya tidak hanya offline tetapi juga harus memasarkan secara online, mayoritas responden sudah memasarkan produk secara online melalui sistem pemasaran yang berbeda-beda, sebanyak 44\% pelaku UMK memilih aplikasi Whatsapp sebagai sarana pemasaran online, 30\% menggunakan instagram, 23\% menggunakan facebook dan 3\% menggunakan aplikasi lainnya. Media whatsapp merupakan media yang dianggap paling mudah untuk digunakan karena mayoritas masyarakat Indonesia di jaman sekarang melakukan komunikasi sosial menggunakan aplikasi whatsapp dan cara penggunaannya yang dianggap mudah.

d) Selain menggunakan sarana media sosial pribadi, sebanyak $46 \%$ responden menggunakan aplikasi e-commerce yaitu Shopee untuk memasarkan produknya, shopee merupakan salah satu ecommerce yang sudah banyak diketahui oleh seluruh masyarakat Indonesia, dengan pemasaran seperti inilah, produk-produk UMK dapat di pasarkan lebih luas.

e) Sebanyak 95\% responden bersedia menjalankan pemasaran online jika disediakan sarana untuk masuk ke digital marketing.

\section{Dampak terhadap Produksi, Biaya dan Keuntungan UMK}

Apabila bisnis UMK dianalisis, yaitu dengan membandingkan produksi sebelum terjadinya pandemi dengan setelah pandemi, maka akan tampak perbedaan yang mencolok. Produksi UMK sebelum pandemi Covid-19 jauh lebih tinggi dibandingkan dengan setelah pandemi seperti disajikan pada Tabel 1.

Tabel 1. Hasil Uji Paired Samples terhadap Omzet Usaha UMK

\begin{tabular}{|c|c|c|c|c|c|}
\hline \multicolumn{2}{|c|}{ Uraian } & Mean & N & t & Sig \\
\hline \multirow{2}{*}{ Omzet } & Sebelum & 7483571.43 & 71 & 5,178 &, 000 \\
\cline { 2 - 4 } & Sesudah & 4184642.86 & 71 & & \\
\hline \multirow{2}{*}{ Biaya } & Sebelum & 4832436.36 & 71 & \multirow{2}{*}{3.862} &, 000 \\
\cline { 2 - 4 } & Sesudah & 3049489.29 & 71 & & \\
\hline
\end{tabular}


Dr. Ir. Dahri Tanjung, M.Si, Safira Fathun, SE., M.Sc.

\begin{tabular}{|l|l|l|l|l|l|}
\hline \multirow{2}{*}{ Keuntungan } & Sebelum & 2651135.07 & 71 & \multirow{2}{*}{5,529} & \multirow{2}{*}{000} \\
\cline { 2 - 4 } & Sesudah & 1135153.57 & 71 & & \\
\hline
\end{tabular}

Sumber: Data Primer, 2020

\section{Dampak terhadap Biaya UMK}

Apabila bisnis UMK dianalisis yaitu dengan membandingkan biaya produksi sebelum terjadinya pandemi dengan setelah pandemi, maka akan tampak perbedaan yang mencolok. Biaya produksi yang dimaksud merupakan total pengeluaran UMK yang diperlukan dalam melakukan proses produksi yang dinyatakan dalam satuan rupiah per bulan (Rp/bulan). Untuk biaya, didapatkan bahwa biaya UMK sebelum pandemi lebih tinggi dibandingkan dengan biaya setelah pandemi. Munawar (2003) menyatakan bahwa pada saat pandemi sebagian pekerja terpaksa dikurangi sebagai salah satu strategi mengurangi biaya. Hasil pengolahan data dapat dilihat pada Tabel 1.

Dari output di atas dapat disimpulkan bahwa terdapat perbedaan biaya yang dikeluarkan untuk usaha sebelum dan sesudah terjadi pandemi. Terlihat dari tabel di atas adanya penurunan biaya. Perbedaan tersebut signifikan dengan $t=3,862$, tingkat signifikan $(\alpha) 5 \%$ dan df (derajat kebebasan) 70 , dapat diperoleh $\mathrm{t}$ hitung $\geq \mathrm{t}$ tabel $(3,862 \geq 2,093)$. Sehingga biaya yang dibutuhkan untuk menjalankan bisnis lebih rendah dibandingkan dengan sebelum terjadi pandemi. Hal ini disebabkan biaya bahan baku lebih rendah, dengan menggunakan volume yang lebih sedikit. Begitu juga dengan biaya tenaga kerja lebih sedikit, karena terpaksa dikurangi. Hasil uji menunjukkan bahwa signifikansi sebesar 0,004 dengan mendasarkan pada nilai probabilitas $(\mathrm{sig}<0,05)$. Hal ini berarti Ho ditolak dan Ha diterima dengan kesimpulan bahwa pada populasi secara statistik ada perbedaan yang bermakna antara biaya yang dikeluarkan untuk usaha sebelum dan sesudah terjadi pandemi. Hal ini didukung oleh Jayadinata (2020) yang menyatakan biaya usaha berkurang di saat pandemi.

\section{Dampak terhadap Pendapatan UMK}

Selanjutnya apabila dikaji pendapatan UMK dengan membandingkan kondisi sebelum dan setelah terjadinya pandemi Covid, maka hasilnya ditampilkan pada Tabel 1. Dari data di atas dapat disimpulkan bahwa ada perbedaan pendapatan yang diperoleh sebelum terjadi pandemi Covid dan sesudah terjadi pandemi. Terlihat ada penurunan pendapatan ketika terjadi pandemi. Perbedaan tersebut signifikan dengan $t=5,529$, tingkat signifikan $(\alpha) 5 \%$ dan df (derajat kebebasan) 59, dapat diperoleh $t$ hitung $\geq t$ tabel $(5,529 \geq 2,000)$. Sehingga pendapatan yang diperoleh UMK lebih rendah dibandingkan dengan sebelum terjadi pandemi. Hal ini karena faktor yang mempengaruhi pendapatan juga berubah, seperti omzet maupun biaya. Sekarang hampir semuanya terkena dampak karena pandemi dan kebijakan lockdown. Hasil uji menunjukkan bahwa signifikansi sebesar 0,000 dengan mendasarkan pada nilai probabilitas (sig < 0,05). Hal ini berarti Ho ditolak dan Ha diterima dengan kesimpulan bahwa pada populasi secara statistik ada perbedaan yang bermakna antara pendapatan yang diperoleh sebelum dan sesudah terjadi pandemi. Hal ini sesuai dengan Rahmad (2008) yang menyatakan bahwa pandemi telah menyebabkan dampak negatif terhadap bisnis UMKM secara global.

Kejadian pandemi Covid ini telah menyebabkan terjadi penurunan omzet UMK yang besarnya rata-rata mencapai $62 \%$. UMK ini adalah kelompok entitas yang paling terancam karena mereka tidak memiliki sumber daya yang cukup untuk bertahan hidup dari krisis. Konsekuensi yang akan terjadi akibat krisis ekonomi ini adalah meningkatnya peran intervensi negara dan lembaga keuangan internasional. Kebijakan negara diambil dalam bentuk penundaan pinjaman dan pembayaran pajak, pengambilalihan beberapa pekerjaan atau biaya jaminan sosial dengan anggaran pusat, memprioritaskan keselamatan dan manajemen bencana (Sulkowski, 2020). 
Dr. Ir. Dahri Tanjung, M.Si, Safira Fathun, SE., M.Sc.

\section{Program Pemulihan UMK dari Covid-19}

a) Penyiapan Izin Standar

Agar dapat bertahan menjalankan usaha dimasa pandemi Covid-19 yang sedang mewabah dan menghadapi era new normal untuk sekarang ini, pelaku UMK dituntut harus bisa menemukan solusi dan manajemen ulang usaha agar mereka dapat bertahan menjalankan usahanya dan tidak merugi. Seluruh upaya tentu saja harus dilakukan agar UMK tetap menjadi salah satu sektor penopang strategis perekonomian nasional.

Berdasarkan keluhan pelaku UMK yang menjadi objek penelitian ini, dapat disimpulkan bahwa wabah Covid-19 sangat berdampak pada bisnisnya, mereka harus mengantisipasi agar ushaanya tetap produktif dan tidak gulung tikar, pilihan tersebut diantaranya tetap mempertahankan posisinya di tengah pandemi dengan berjualan produk UMK melalui pemasaran online. Menawarkan produk dengan harga terjangkau namun berkualitas.

b) Perbaikan Kualitas Produk

Perbaikan yang dilakukan oleh para pelaku UMK terhadap bisnisnya ialah para UMK harus mampu memperbaiki baik dari segi mutu produk secara fisik, organoleptik, umur produk, kemasan serta yang paling terpenting adalah mengenai regulasi P-IRT agar para pelaku UMK dapat bersaing di pasaran. Perbaikan kualitas yang didapat yaitu 1) memperbaiki dari segi fisik, organoleptik meliputi warna, aroma, rasa, tekstur dan penampakan 2) tampilan dan fungsional kemasan dan produk dibuat lebih menarik, rapat dan mudah dibuka maupun ditutup kembali, 3) membuat deskripsi produk untuk dilakukan tahapan branding produk untuk pemasaran melalui ke tahapan digital marketing, 4) melakukan dan mengurus perizinan P-IRT agar produk UMK menjadi lebih unggul dibandingkan dengan produk lain serta untuk meyakinkan bahwasanya produk UMK aman dikonsumsi oleh masyarakat karena telah melalui pengontrolan dari Dinas Kesehatan, 5) Pencantuman komposisi bahan yang digunakan dalam produk pada label kemasan untuk meyakinkan kepada konsumen bahwa bahan yang digunakan bahan makanan, bahan tambahan pangan yang diizinkan, aman dan halal. 6) Umur simpan atau masa kadaluarsa yang panjang menjadi indikator kualitas yang baik. Umur simpan yang dapat diperoleh dengan menerapkan cara pengolahan pangan yang baik. 7) Daya tahan produk dapat seperti tidak mudah berubah bentuk, tidak mudah meleleh, tidak mudah hancur juga menjadi syarat yang diperlukan pada saat era pandemi. Produk dengan umur simpan yang panjang dan daya tahan yang tinggi dapat memperluas jangkauan daerah pemasaran.

\section{c) Pengembangan Digital Marketing}

Di era pandemi ini, berkembang kegiatan jual beli dengan digital marketing melalui marketplace maupun media sosial. Perkembangan ini harus diikuti oleh UMK agar tidak ditinggalkan oleh masyarakat. Untuk dapat menjual produknya secara online melalui media sosial ataupun digital marketing produk UMK harus bisa memenuhi standar yang harus ada dalam produk yang dijual. Salah satu standar agar bisa memasuki pemasaran online yaitu adanya perbaikan kualitas kemasan, kemasan produk harus mampu melindungi produk dari cemaran fisik, kimia, mikriobiogi, memperpanjang umur simpan dan menjaga produk dari benturan dan bantingan selama pengiriman. Kemasan juga harus dilengkapi dengan label kemasan yang berfungsi sebagai alat penyampaian informasi dan pesan dari UMK kepada pelanggan. Label kemasan harus mencantumkann nama produk, merek, alamat produsen, komposisi, tanggal produksi, tanggal kadaluarsa, berat bersih, foto 
Dr. Ir. Dahri Tanjung, M.Si, Safira Fathun, SE., M.Sc.

produk, rasa produk (bila makanan atau minuman), informasi nilai gizi, dan informasi perizinan lainnya seperti halal, BPOM, PIR-T, laik sehat maupun SNI.

UMK juga harus berupaya mendapatkan izin usaha dan izin edar agar usaha mereka legal secara hukum. Cara mengurus perizinan pelaku usaha khususnya UMK, pada penelitian ini dibuat suatu Buku panduan yang didalamnya dijabarkan syarat-syarat dan prosedur pengurusan izin usaha. Selian itu, di dalam buku panduan di jelaskan bagaimana prosedur agar dapat melakukan digital marketing melalui sosial media dan platform digital marketing lainnya.

Beruntung, pemerintah saat ini cukup berani mengambil kebijakan dengan tidak memberlakukan lockdown full, sehingga beberapa UMK di daerah masih punya kesempatan untuk mencari cara agar tetap bisa 'bertahan hidup'. Selain itu, ada beberapa kebijakan lainnya yang dinilai cukup membantu para pelaku UMK, misalnya memberikan relaksasi kredit, menggratiskan dan diskon listrik hingga 50\%, serta program kemudahan suntikan modal.

Membuka aturan PSBB dan WFH dan diganti dengan pola hidup sehat dengan memakai masker, tetap menjaga jarak dan mencuci tangan. Hal ini perlu dilakukan agar iklim usaha bagi UMK kembali terbuka karena sangat sedikit UMK yang mampu dan memanfaatkan marketplace. Namun, untuk beberapa UMK yang mempunyai peluang ke digital marketing perlu didorong dengan memperbaiki kualitas produknya sehingga memenuhi syarat standarisasi, memperbaiki kemasan produknya, menyediakan permodalan tambahan yang mudah diakses UMK, dan memanfaatkan digital marketing yang ada. Karena biar bagaimanapun di masa pandemi ini digitalisasi sudah merupakan suatu keniscayaan apalagi di era industry 4.0.

Dalam krisis seperti ini, tidak sedikit sektor usaha UMK yang berjuang agar tetap eksis. Usaha ini seringkali sulit bertahan karena keterbatasan permodalan. Keberadaan UMK sebagai kelompok yang sangat rentan untuk jatuh ke dalam jurang kemiskinan dan kebangkrutan karena goncangan atau hantaman ekonomi. Dengan demikian salah satu langkah pemulihan yang perlu dilakukan adalah pemberian tambahan modal kepada UMK. Pemberian modal usaha dijadikan sebagai sarana mengurangi dampak krisis. Pemberian modal ini dapat dilakukan dengan beberapa alternatif kebijakan, seperti pemberian stimulasi tambahan relaksasi perbankan termasuk syariah dan restrukturisasi atau penangguhan pembayaran kredit/pembiayaan syariah selama beberapa bulan ke depan. Pemberian permodalan dari perbankan/lembaga keuangan ini perlu didukung dan dikuatkan dengan pendampingan sehingga dapat dipertanggungjawabkan.

\section{Kesimpulan}

Wabah pandemi Covid-19 telah menyebabkan volume pemasaran produk UMK menurun drastis. Dampak lanjutannya menyebabkan menurunnya omzet usaha (62\%) dan menurunkan pendapatan UMK. Sementara pelaku UMK tersebut belum mampu memasarkan produk secara digital marketing karena rumitnya administrasi dan teknis dalam pemasaran digital. Untuk itu produk-produk UMK yang ingin dipasarkan secara digital marketing perlu diperbaiki dari segi kemasan dan atribut kemasan untuk daya tarik pembeli serta melengkapi perizinan usaha sehingga akan memudahkan untuk memasuki digital marketing. Pelaku UMK juga membutuhkan suatu model pemberdayaan yang bisa membantu mereka terkait teknis digital marketing dan perizinan usaha tersebut. Untuk itu disarankan adanya pendampingan dan penyuluhan secara kontinu sampai pelaku UMK bisa menerapkannya digital marketing menuju pemulihan bisnis mereka. 


\section{Ucapan terima kasih}

Ucapan terima kasih disampaikan kepada Pimpinan Sekolah Vokasi IPB Bogor atas dukungannya dalam pendanaan Riset Hibah SV 2020.

\section{Daftar Pustaka}

Albulescu, C. (2020). Coronavirus and Oil Price Crash. Available at SSRN: https://ssrn.com/abstract=3553452 or http://dx.doi.org/10.2139/ssrn.3553452

Fitriasari, F. (2020). How do Small and Medium Enterprise (SME) survive the COVID-19 outbreak? Jurnal Inovasi Ekonomi Vol. 05 No. 02 June 2020 Page 53-62 Special Issue of Economic Challenges in COVID-19 Outbreak P-ISSN: 2477-4804E-ISSN: 26863804. http://ejournal.umm.ac.id/index.php/jiko.

Miswanto and Vajrin S.A. (2019). Analisis Kinerja Keuangan: Sesudah dan Sebelum Krisis Ekonomi Global 2008 pada Perusahaan Manufaktur di Indonesia. BALANCE: Jurnal Akuntansi, Auditing dan Keuangan Vol.16. No. 1 Maret 2019: 22-40. https://doi.org/10.25170/balance.v16i1.80

OECD. (2020) Coronavirus (COVID-19): SME Policy Responses. Tackling Coronavirus (COVID-19): Contributing to a Global Effort. https://www.oecd.org/coronavirus/en/

Omar, ARC., Ishak, S., Jusoh, MA. (2020). The Impact of Covid-19 Movement Control Order on SMEs' Businesses and Survival Strategies. GEOGRAFIA Online TM Malaysian Journal of Society and Space. Vol. 16 issue 2 (139-150). Diakses dari : https://doi.org/10.17576/geo-2020-1602-11

Pakpahan, A.K. (2020). COVID-19 dan Implikasi Bagi Usaha Mikro, Kecil, dan Menengah. http://journal.unpar.ac.id/index.php/JurnalIlmiahHubunganInternasiona/article/downl oad/3870/2903

Pardian, P, Elly R, Endah D, and Bobby R.S. (2017). Persepsi dan Minat Petani Muda dalam Budidaya Sayuran Swiss Chard Organik. Dharmakarya: Jurnal Aplikasi Ipteks untuk Masyarakat, Vol. 6, No. 3, September 2017: 163 - 166. ISSN 1410 - 5675.

Sulkowski, A. J. (2020). COVID-19: What's Next? Future of Work, Business, and Law: Automation, Transparency, Blockchain, Education, and Inspiration. SSRN Electronic Journal. https://doi.org/10.2139/ssrn.3580019

Tambunan, M. (2011). Teori Ekonomi Makro, Fakultas Ekonomi Universitas Indonesia, Jakarta.

Papadopoulos, T, Konstantinos N. B, and Balta, M. E. (2020). The use of digital technologies by small and medium enterprises during COVID-19: Implications for theory and practice. International Journal of Information Management, Vol 55 Desember 2020. 